Original Article

\title{
Interspecific variations in external and internal egg quality among various captive avian species from Punjab, Pakistan
}

\author{
Variações interespecíficas na qualidade externa e interna do ovo entre várias espécies \\ de aves em cativeiro de Punjab, Paquistão
}

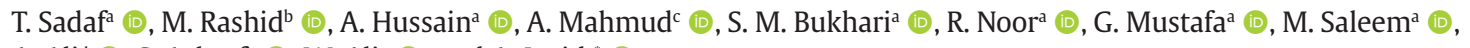
A. Ali ${ }^{\text {(D) S. Ashrafe (D, W. Ali }}{ }^{\text {(D) }}$ and A. Javida ${ }^{*}$ (D)

a University of Veterinary and Animal Sciences, Department of Wildlife and Ecology, Lahore, Pakistan

${ }^{\mathrm{b}}$ University of Veterinary and Animal Sciences, Faculty of Fisheries and Wildlife, Lahore, Pakistan

c University of Veterinary and Animal Sciences, Department of Poultry Production, Lahore, Pakistan

${ }^{\mathrm{d}}$ The Islamia University of Bahawalpur, Department of Zoology, Bahawalpur, Paistan

e The University of Lahore, Department of Zoology, Sargodha Campus, Sargodha, Pakistan

\begin{abstract}
Present study was planned to determine variations in external and internal quality egg parameters of different avian species including ostrich Struthio camelus, ducks Anas platyrhynchos, chicken Gallus gallus, turkeys Meleagris gallopavo and grey francolin Francolinus pondicerinus. All the birds were kept under similar rearing conditions. A total of 150 eggs were collected for each species to record external features of these eggs. Statistically significant $(p<0.05)$ variations were recorded in egg weight, egg length and egg width between ostrich, ducks, chicken, turkey and quail eggs. Significantly ( $\mathrm{p}<0.05)$ higher egg weight, egg length and egg width was observed for ostrich eggs while the same was lowest for grey francolin eggs. Similarly, significantly $(p<0.05)$ greater shape index and egg volume values were observed for ostrich eggs while lowest shape index values were recorded for turkey eggs and egg volume was lowest for grey francolin. Significantly, higher $(p<0.05)$ values of egg density were noted for eggs of the quail and the same were lowest for ostrich eggs. Non-significant variations in egg density values were observed between eggs of the ducks, chicken, turkey and grey francolin. It has been concluded that the positive correlations between the internal and external egg quality traits indicated that the traits can be improved through selection.
\end{abstract}

Keywords: ostrich, ducks, egg weight, egg density, shape index.

\begin{abstract}
Resumo
O presente estudo foi planejado para determinar variações nos parâmetros externos e internos de qualidade dos ovos de diferentes espécies de aves, incluindo avestruz Struthio camelus, patos Anas platyrhynchos, frango Gallus gallus, perus Meleagris gallopavo e francolin cinza Francolinus pondicerinus. Todas as aves foram mantidas em condições de criação semelhantes. Um total de 150 ovos foi coletado para cada espécie para registrar as características externas desses ovos. Variações estatisticamente significativas $(\mathrm{p}<0,05)$ foram registradas no peso do ovo, comprimento do ovo e largura do ovo entre os ovos de avestruz, patos, galinha, peru e codorna. Significativamente $(\mathrm{p}<0,05)$ maior peso do ovo, comprimento e largura do ovo foram observados para ovos de avestruz, enquanto o mesmo foi menor para ovos de francolina cinza. Da mesma forma, significativamente $(\mathrm{p}<0,05)$ maiores valores de índice de forma e volume de ovo foram observados para ovos de avestruz, enquanto os menores valores de índice de forma foram registrados para ovos de peru e o volume de ovo foi menor para francolina cinza. Significativamente, maiores $(\mathrm{p}<0,05)$ valores de densidade de ovos foram observados para ovos de codorna e os mesmos foram menores para ovos de avestruz. Variações não significativas nos valores de densidade de ovos foram observadas entre os ovos de pato, frango, peru e francolina cinza. Concluiu-se que as correlações positivas entre as características internas e externas de qualidade do ovo indicaram que as características podem ser melhoradas por meio da seleção.
\end{abstract}

Palavras-chave: avestruz, patos, peso do ovo, densidade do ovo, índice de forma.

\section{Introduction}

Egg is considered as natural reproductive site, it provides balanced diet to developing embryo and also serves as food source for chick's first days of life
(Abanikannda et al., 2007). Egg quality indicates those characters of egg that contributes it's acceptability towards consumer (Altinel et al., 1996). External egg quality

*e-mail: arshadjavid@uvas.edu.pk

Received: November 4, 2020 - Accepted: November 30, 2020 
parameters including shell weight, egg weight, freshness and cleanliness play role in consumer's acceptability. Meanwhile, internal factors such as haugh unit, yolk index, yolk height, albumin height, albumin width are considered by industry as demand for liquid egg, frozen egg, powder egg increasing day by day (Silversides et al., 2006). In poultry industry internal and external traits of eggs are influencing growth quality, future generation and breeding performance (Di Rosa et al., 2020)

The efficiency of a breeding operation can be checked by number of quality chicks obtained and the number of quality eggs produced. Any shortcomings in physical specifications of an egg have adverse effect on healthy development of the embryo. Moreover, egg weight, egg size and shape index are of significance for hatchability. It is well documented that the rate of survival of chicks from small to large eggs are low as compared to medium sized eggs. Because larger eggs have poor hatchability rate and smaller eggs yield too small chicks. Therefore, medium sized eggs are recommended for incubation (Sahin et al., 2009).

For improving broiler and pullet efficacy and consistency an accurate prediction of chick weight before incubation is helpful in developing breeding programs (Wilson, 1991). In the domestic fowl, egg weight represents the chick weight normally being $61-76 \%$ of initial egg weight, and in the course of incubation is determined by weight loss and strain genetic differences, weight of shell and other residues at hatch, incubation time and conditions, chick sex and breeder age (Shanawany, 1987; Wilson 1991, 1992). In determining the livability, health and growth the main factor is the newly hatched chick (Sklan et al., 2003). Chick weight measured as an exact interpreter of final body weight whereas for others this has not been the case ( $\mathrm{Di}$ Rosa et al., 2020; Shanawany, 1987; Ashraf et al., 2016).

Relationship between egg quality parameters and its relation with chick weight is predictable in chicken although must be discovered in other avian species. Clutch production in oviparous animals, represents giant investment in terms of reserves allotted to eggs and energy in a restricted time period (Nager, 2006). It has been revealed in avian species, that egg mass is extremely heritable and repeatable at individual level proposing a strong genetic constituent (Christians, 2002). Environmental constituents for example health conditions and food availability of the laying female contribute in egg and mass composition of intra-clutch variations (Birkan and Jacob, 1988; Ardia and Clotfelter, 2006). The relations of egg also play a very important role, present study is therefore planned to find out the external and internal egg parameters in selected avian species.

\section{Materials and Methods}

Present study was planned to determine variations in external and egg quality parameters in some captive avian species. Eggs of ostrich Struthio camelus, ducks Anas platyrhynchos, chicken Gallus gallus, turkeys Meleagris gallopavo and grey francolin Francolinus pondicerinus were collected from Avian Conservation and Research Center, Department of Wildlife and Ecology, Ravi Campus, University of Veterinary and Animal Sciences, Lahore.

\subsection{External and internal egg quality parameters}

The weight of each egg was measured using digital weighing balance (Mettler Toledo, PL203 CE) with accuracy of $0.001 \mathrm{~g}$ while egg length and egg width were recorded using a vernier caliper. Egg volume, egg density and shape index were determined using following formulae (1-8);

$$
\begin{aligned}
& \text { Egg volume }\left(\mathrm{cm}^{3}\right)=\mathrm{K} \pi \mathrm{LB}^{2} / 6 \\
& \text { Egg density }\left(\mathrm{g} / \mathrm{cm}^{3}\right)= \\
& =\text { Egg weight }(\mathrm{g}) / \text { Egg volume }\left(\mathrm{cm}^{3}\right) \\
& \text { Shape index of egg }= \\
& =\text { Short axis of egg / long axis of egg } \times 100
\end{aligned}
$$

Shell thickness: Shell thickness was measured from all ends (broader ends, middle ends, tapering ends) using screw gauge. Average shell thickness (with membrane) was measured from the average values of these three poles.

\subsection{Internal egg quality parameters}

Albumin height and length were measured by using venire caliper while albumin index (\%) and albumin ratio (\%) were recorded using following formulase;

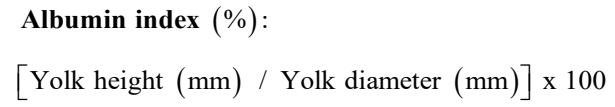

Albumin ratio (\%):

[Albumen weight (g) / Egg weight $(\mathrm{g})] \times 100$

Similarly, yolk height $(\mathrm{mm})$ and width $(\mathrm{cm})$ were measured by using venire caliper while yolk index and yolk ratio were determined using following formulas;

\section{Yolk index $(\%)$ :}

$[$ Yolk height $(\mathrm{mm}) /$ Yolk diameter $(\mathrm{mm})] \times 100$

Yolk ratio $(\%)$ :

[Yolk weight (g) / Egg weight (g) x 100

Albumin and yolk weight were measured by using weighing balance.

Shell weight: Cleaned the eggs from albumin residues, the egg shells were washed with water, dried at room temperature and weighed using electronic digital weighing balance.

Haugh unit $(\mathrm{Hu})$ : The Huagh unit is measurement of egg protein quality based on height of egg white and is calculated by formula; 


$$
100 \log 10[\mathrm{H}-1.7 \mathrm{w} 0.37+7.6]
$$

Shell thickness, shell membrane thickness, shell ratio, yolk ratio, albumen ratio and Haugh unit were determined following Kirikci et al. (2004) and Abd Salman Abu Tabeekh (2011).

\subsection{Statistical analysis}

Mean and standard deviation values were computed through the statistical software Microsoft Excel (Version 2010) and interspecific variations in external and internal egg quality parameters were determined by applying Analysis of Variance (ANOVA) through statistical software SAS 9.1.

\section{Results}

\subsection{External egg quality parameters of various avian species}

Species-wise variations in external egg quality parameters of ostrich Struthio camelus, turkeys Meleagris gallopavo, ducks Anas platyrhynchos, chicken Gallus gallus and grey francolin Francolinus pondicerinus are mentioned in Table 1.

The external quality parameters of ostrich $S$. camelus eggs ( $n=30$ ) are as fallow. Mean egg weight of all the eggs was $1024.4 \pm 3.78 \mathrm{~g}$, average egg length and egg width was $15.21 \pm 0.173 \mathrm{~cm}$ and $10.59 \pm 0.32 \mathrm{~cm}$, respectively. Mean shape index was computed $69.62 \pm 1.50 \mathrm{~cm}$, mean egg volume was $831.22 \pm 58.99 \mathrm{~cm}^{3}$ and mean egg density was $0.15 \pm 0.008 \mathrm{~g} / \mathrm{cm}^{3}$.

Similarly, mean weight, egg length, egg width, shape index, egg volume and egg density of turkey M. gallopavo eggs $(\mathrm{n}=30)$ was recorded $82.89 \pm 1.836 \mathrm{~g}$, $6.26 \pm 0.201 \mathrm{~cm}, 4.32 \pm 0.092 \mathrm{~cm}, 69.06,56.90 \pm 3.46 \mathrm{~cm}^{3}$ and $1.46 \pm 0.07 \mathrm{~g} / \mathrm{cm}^{3}$ respectively.

Average weight of $A$. platyrhynchos eggs $(\mathrm{n}=30)$ was $54.60 \pm 5.56 \mathrm{~g}$, egg length was $5.41 \pm 0.23 \mathrm{~cm}$, egg width $3.72 \pm 0.22 \mathrm{~cm}$, shape index $68.74 \pm 2.16$, egg volume $36.69 \pm 5.84 \mathrm{~cm}^{3}$ while egg density was recorded $1.52 \pm 0.26 \mathrm{~g} / \mathrm{cm}^{3}$.

Mean egg weight, egg length, egg width, shape index, egg volume and egg density of G. gallus eggs $(\mathrm{n}=10)$ was recorded $67.14 \pm 7.70 \mathrm{~g}, 5.56 \pm 0.35 \mathrm{~cm}, 4.06 \pm 0.16 \mathrm{~cm}$,
$73.17 \pm 3.22,44.82 \pm 6.06 \mathrm{~cm}^{3}$ and $1.52 \pm 0.07 \mathrm{~g} / \mathrm{cm}^{3}$, respectively.

Average weight of the $F$. pondicerinus eggs $(n=30)$ was $11.77 \pm 1.15 \mathrm{~g}$, egg length was $2.77 \pm 0.12 \mathrm{~cm}$, egg width was $2.21 \pm 0.14 \mathrm{~cm}$, mean shape index was $79.79 \pm 3.68$, egg volume was $6.63 \pm 1.01 \mathrm{~cm}^{3}$ and egg density was $1.80 \pm 0.20$.

\subsection{Internal egg quality parameters of various avian species}

The internal egg quality parameters of the birds analyzed during present study are mentioned in Table 2. Internal egg quality parameters of Ostrich S. camelus eggs $(n=30)$ including average albumin weight was $52.05 \pm 0.16 \%$, yolk weight was $28.42 \pm 0.13 \%$, shell weight was $19.51 \pm 0.12 \%$, average albumin height was $1.71 \pm 0.09 \mathrm{~cm}$, yolk height was $3.17 \pm 0.13 \mathrm{~cm}$, mean yolk diameter was $10.83 \pm 3.18 \mathrm{~cm}$, shell thickness was $2.36 \pm 0.11 \mathrm{~mm}$ while $\mathrm{pH}$ of albumin and yolk were recorded $8.42 \pm 0.26$ and $6.48 \pm 0.24$, respectively. Haugh unit was observed $73.57 \pm 4.05$.

Similarly, average albumin weight, yolk weight, shell weight, albumin height, yolk height, yolk diameter, shell thickness, albumin $\mathrm{pH}$, yolk pH and Haugh unit of turkey Meleagris gallopavo eggs $(\mathrm{n}=30)$ was recorded $58.82 \pm 1.16 \%$, $29.61 \pm 1.02 \%, 11.56 \pm 0.60 \%, 0.66 \pm 0.139 \mathrm{~cm}, 1.28 \pm 0.11 \mathrm{~cm}$, $4.04 \pm 0.13 \mathrm{~cm}, 0.28 \pm 0.02 \mathrm{~mm}, 8.44 \pm 0.19,6.25 \pm 0.05$ and $72.62 \pm 10.10$, respectively.

Average albumin weight of $A$. platyrhynchos eggs ( $n=30$ ) was recorded $49.32 \pm 0.91 \%$, mean yolk weight was $36.36 \pm 2.15 \%$, shell weight $14.31 \pm 1.33 \%$, albumin height was $0.41 \pm 0.09 \mathrm{~cm}$, yolk height $1.72 \pm 0.23 \mathrm{~cm}$, yolk diameter was $4.68 \pm 0.20 \mathrm{~cm}$, shell thickness was $0.33 \pm 0.01 \mathrm{~mm}$, mean albumin $\mathrm{pH} 8.0 \pm 0.04$ and yolk $\mathrm{pH}$ was $6.09 \pm 0.02$. Haugh unit was $61.44 \pm 9.88$. Mean albumin weight, yolk weight, shell weight, albumin height, yolk height, yolk diameter, shell thickness, albumin pH, yolk $\mathrm{pH}$ and Haugh unit of G. gallus eggs $(\mathrm{n}=30)$ was observed $59.12 \pm 4.63 \%, 28.60 \pm 3.70 \%, 12.26 \pm 1.10 \%, 0.47 \pm 0.22 \mathrm{~cm}$, $1.25 \pm 0.14 \mathrm{~cm}, 3.72 \pm 0.24 \mathrm{~cm}, 0.20 \pm 0.02 \mathrm{~mm}, 8.70 \pm 0.38$, $6.27 \pm 0.12$ and $58.75 \pm 19.05$ respectively.

Average albumin weight of $F$. pondicerinus eggs $(\mathrm{n}=30)$ was $38.58 \pm 1.50 \%$, yolk weight was $46.47 \pm 1.71 \%$, shell weight was $14.94 \pm 0.45 \%$, albumin height was $0.09 \pm 0.01 \mathrm{~cm}$, yolk height was $0.65 \pm 0.11 \mathrm{~cm}$, yolk diameter was $2.05 \pm 0.13 \mathrm{~cm}$, shell thickness was $0.30 \pm 0.08 \mathrm{~mm}$. Average albumin and yolk pH was $8.83 \pm 0.06$ and $6.06 \pm 0.02$, respectively. Haugh unit was calculated $63.19 \pm 1.40$.

Table 1. Variations in external egg quality parameters in selected avian species.

\begin{tabular}{ccccccc}
\hline \multirow{2}{*}{ Avian species } & \multicolumn{5}{c}{ Parameters } \\
\cline { 2 - 7 } & $\begin{array}{c}\text { Egg weight } \\
(\mathbf{g})\end{array}$ & $\begin{array}{c}\text { Egg length } \\
(\mathbf{c m})\end{array}$ & $\begin{array}{c}\text { Egg width } \\
(\mathbf{c m})\end{array}$ & Shape index & $\begin{array}{c}\text { Egg volume } \\
\left(\mathbf{c m}^{3}\right)\end{array}$ & $\begin{array}{c}\text { Egg density } \\
\left(\mathbf{g} / \mathbf{c m}^{3}\right)\end{array}$ \\
\hline Struthio camelus & $124.94 \pm 3.82^{\mathrm{A}}$ & $15.21 \pm 0.17^{\mathrm{A}}$ & $10.59 \pm 0.32^{\mathrm{A}}$ & $69.61 \pm 1.50^{\mathrm{D}}$ & $831.22 \pm 58.99^{\mathrm{A}}$ & $0.15 \pm 0.08^{\mathrm{C}}$ \\
Meleagris gallopavo & $82.89 \pm 1.83^{\mathrm{B}}$ & $6.26 \pm 0.20^{\mathrm{B}}$ & $4.32 \pm 0.09^{\mathrm{B}}$ & $69.06 \pm 2.34^{\mathrm{E}}$ & $56.90 \pm 3.46^{\mathrm{B}}$ & $1.46 \pm 0.07^{\mathrm{B}}$ \\
Anas platyrhynchos & $54.60 \pm 5.55^{\mathrm{D}}$ & $5.41 \pm 0.23^{\mathrm{C}}$ & $3.72 \pm 0.22^{\mathrm{D}}$ & $68.74 \pm 2.16^{\mathrm{E}}$ & $36.69 \pm 5.83^{\mathrm{B}}$ & $1.51 \pm 0.25^{\mathrm{B}}$ \\
Gallus gallus & $67.73 \pm 6.76^{\mathrm{C}}$ & $5.56 \pm 0.35^{\mathrm{C}}$ & $4.06 \pm 0.16^{\mathrm{C}}$ & $73.16 \pm 3.21^{\mathrm{C}}$ & $44.82 \pm 6.06^{\mathrm{B}}$ & $1.51 \pm 0.06^{\mathrm{B}}$ \\
Francolinus pondicerinus & $11.77 \pm 1.14^{\mathrm{F}}$ & $2.77 \pm 0.11^{\mathrm{F}}$ & $2.21 \pm 0.13^{\mathrm{F}}$ & $79.78 \pm 3.67^{\mathrm{A}}$ & $6.63 \pm 1.01^{\mathrm{D}}$ & $1.79 \pm 0.19^{\mathrm{A}}$ \\
\hline
\end{tabular}

Means with different letters in a column are statistically significant at $\mathrm{p}<0.05$. 


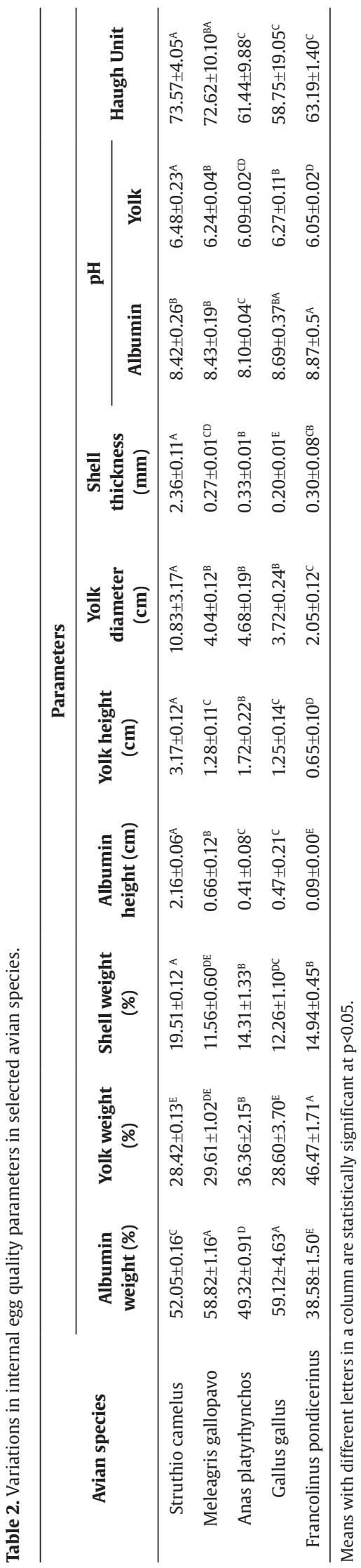


Significantly $(\mathrm{p}<0.05)$ higher egg volume, egg weight, egg length and egg width, were observed for the eggs of ostrich Struthio camelus than all the other avian species. Similarly, egg weight varied significantly between Meleagris gallopavo, Gallus gallus, Anas platyrhynchos and Francolinus pondicerinus. Significantly $(\mathrm{p}<0.05)$ lower values for egg length, egg width and egg weight were recorded in Francolinus pondicerinus eggs. Statistically significant $(\mathrm{p}<0.05)$ variations in shape index were recorded between the eggs of S. camelus, M. gallopavo, G. gallus and F. pondicerinus. Significantly $(p<0.05)$ higher values of shape index were observed for the eggs of F. pondicerinus followed by G. gallus and $S$. camelus while lower shape index values were noted in M. gallopavo and A. platyrhynchos eggs. Maximum egg density was recorded for $F$. pondicerinus egg while the same was lowest for $S$. camelus. However, non-significant variations in egg density were observed among all the other species. Significantly $(\mathrm{p}<0.05)$ lower egg volume was recorded in the eggs of $F$. pondicerinus while non-significant variations were observed among the eggs of M. gallopavo and G. gallus.

\section{Discussion}

During present study, significantly $(\mathrm{p}<0.05)$ higher egg weight $1024.94 \pm 3.82 \mathrm{~g}$ was recorded in Struthio camelus. These results are in-line with the finding of Moreki et al. (2016) who reported similar egg weight in S. camelus. However, Arul Mozhi Selvan et al. (2014) reported higher egg weight in ostrich $1435.1 \pm 20.10 \mathrm{~g}$. The difference in weight of eggs might be due to different strains and body weight. Similarly, eggs of $S$. camelus had significantly $(p<0.05)$ higher egg length, egg width and egg volume than all the other avian species investigated during present study. These results confirm the findings of Arul Mozhi Selvan et al. (2014) who reported similar egg length, width and volume in ostrich eggs. These results are attributed to higher body weight and heavier egg size of ostrich than other species. During present study, higher egg density was observed in Francolinus pondicerinus followed by Meleagris gallopavo, Gallus gallus, Anas platyrhynchos, F. pondicerinus and $S$. camelus. Significantly $(\mathrm{p}<0.05)$ higher values of shape index were observed for the eggs of $F$. pondicerinus followed by; G. gallus and S. camelus eggs. Significantly $(\mathrm{p}<0.05)$ lower egg volume was recorded in the eggs of F. pondicerinus while non-significant variations were observed among the eggs of M. gallopavo and G. gallus.

Higher values of albumin were observed in the eggs of Gallus gallus followed by M. gallopavo, S. camelus and A. platyrhynchos. Similarly, significant $(p<0.05)$ variations in yolk weight was recorded between the eggs of $S$. camelus, A. platyrhynchos and $F$. pondicerinus. Significantly $(\mathrm{p}<0.05)$ lower values of shell weight were observed for the eggs of $A$. platyrhynchos and $F$. pondicerinus while the same was highest for $S$. camelus eggs. Similar results for the percentage of albumin, yolk and shell were reported by Horbanczuk (2002), Kuli and Seker (2004). It has been concluded that the positive correlations between the internal and external egg quality traits indicated that the traits can be improved through selection.

\section{References}

ABANIKANNDA, O.T.F., OLUTOGUN, O., LEIGH, A.O. and AJAYI, L.A., 2007. Statistical modeling of egg weight and egg dimensions in commercial layers. International Journal of Poultry Science, vol. 6, pp. 59-63.

ABD SALMAN ABU TABEEKH, M., 2011. Evaluation of some external and internal egg quality traits of quails reared in Basrah City. Magallat al-Basrat Li-l-Abhat al-Baytariyyat, vol. 10, no. 2, pp. 78-84. http://dx.doi.org/10.33762/bvetr.2011.55029.

ALTINEL, A., GUNES, H., KIRMIZIBAYRAK, T., COREKCI, S.G. and BILAL, T., 1996. The studies on egg quality characteristics of Japanese quails. Istanbul Üniversitesi Veteriner Fakültesi Dergisi, vol. 22, pp. 203-213.

ARDIA, D.R. and CLOTFELTER, E.D., 2006. Individual quality and age affect responses to an energetic constraint in a cavitynesting bird. Behavioral Ecology, vol. 18, no. 1, pp. 259-266. http:// dx.doi.org/10.1093/beheco/arl078.

ARUL MOZHI SELVAN, V., ANAND, R.B. and UDAYAKUMAR, M., 2014. Effect of Cerium Oxide Nanoparticles and Carbon Nanotubes as fuel-borne additives in Diesterol blends on the performance. combustion and emission characteristics of a variable compression ratio engine. Fuel, vol. 130, pp. 160-167. http://dx.doi.org/10.1016/j.fuel.2014.04.034.

ASHRAF, S., JAVID, A., AKRAM, M., MALIK, S., IRFAN and ALTAF, M., 2016. Influence of egg weight on egg quality parameters and growth traits in ring necked pheasants. Journal of Animal and Plant Sciences, vol. 26, pp. 331-338.

BIRKAN, M. and JACOB, M., 1988. The grey partridge. Paris: Hatier.

CHRISTIANS, J.K., 2002. Avian egg size: variation within species and inflexibility within individuals. Biological Reviews of the Cambridge Philosophical Society, vol. 77, no. 1, pp. 1-26. http:// dx.doi.org/10.1017/S1464793101005784. PMid:11911371.

DI ROSA, A.R., CHIOFALO, B., LO PRESTI, V., CHIOFALO, V. and LIOTTA, L., 2020. Egg quality from siciliana and livorno italian autochthonous chicken breeds reared in organic system. Animals (Basel), vol. 10, no. 5, pp. 864-866. http://dx.doi.org/10.3390/ ani10050864. PMid:32429459.

HORBANCZUK, J.O., 2002. The history and current status of ostrich farming in Poland. In Proceedings of World Ostrich Congress, 2002, Warsaw, Poland: European Ostrich Group, pp. 7-13.

KIRIKCI, K., ÇETIN, O., GÜNLÜ, A. and GARIP, M., 2004. Effect of hen weight on egg production and some egg quality characteristics in pheasants (Phasianus colchicus). Asian-Australasian Journal of Animal Sciences, vol. 17, no. 5, pp. 684-687. http://dx.doi. org/10.5713/ajas.2004.684.

KULI and SEKER, D.M., 2004. The programme for calcula-tion of the line asymmetry in spectrum of the Sun and stars. Azerbaijão: Baku State University, vol. 2, pp. 158-165. Report.

MOREKI, J.C., NELSON, K. and BOITUMELO, W., 2016. Assessment of management practices of Tswana chickens at North East District of Botswana. Journal of Veterinary Medicine and Animal Sciences, vol. 1, pp. 29-38.

NAGER, R.G., 2006. The challenges of making eggs. Ardea, vol. 94, pp. 323-346.

SAHIN, H., CAHANGIROV, S., TOPSAKAL, M., BEKAROGLU, E., AKTURK, E., SENGER, R.T. and CIRACI, S., 2009. Monolayer honeycomb structures of group-IV elements and III-V binary compounds: first-principles calculations. Physical Review. B, vol. 80, no. 15, pp. 155453. http://dx.doi.org/10.1103/PhysRevB.80.155453.

SHANAWANY, M.M., 1987. Hatching weight in realation to egg weight in domestic bird. World's Poultry Science Journal, vol. 43, no. 2, pp. 107-115. http://dx.doi.org/10.1079/WPS19870008. 
SILVERSIDES, F.G., SCOTT, T.A., KORVER, D.R., AFSHARMANESH, M. and HRUBY, M., 2006. A study on the interaction of xylanase and phytase enzymes in wheat-based diets fed to commercial white and brown egg laying hens. Poultry Science, vol. 85, no. 2, pp. 297-305. http://dx.doi.org/10.1093/ps/85.2.297. PMid: 16523630

SKLAN, D., SMIRNOV, A. and PLAVNIK, I., 2003. The effect of dietary fibre on the small intestines and apparent digestion in the turkey. British Poultry Science, vol. 44, no. 5, pp. 735-
740. http://dx.doi.org/10.1080/00071660310001643750. PMid:14965095.

WILSON, H.R., 1991. Interrelationship of egg size, chick size, post hatching growth and hatchability. World's Poultry Science Journal, vol. 47, no. 1, pp. 5-20. http://dx.doi.org/10.1079/ WPS19910002.

WILSON, H.R., 1992. Physiological requirements of the developing embryo: temperature and turning. In S.G. Tullet, ed. Avian incubation. USA: Butterworth-Heinemann, pp. 145-156. 